\title{
Overexpression of c-erbB2 is a negative prognostic factor in anaplastic astrocytomas
}

\author{
Sasha Gulati ${ }^{1,2^{*}}$, Borgny Ytterhus ${ }^{2}$, Unn S Granli ${ }^{2}$, Michel Gulati ${ }^{4}$, Stian Lydersen ${ }^{5}$, Sverre H Torp ${ }^{2,3}$
}

\begin{abstract}
The epidermal growth factor receptor (EGFR) family, consisting of four tyrosine kinase receptors, c-erbB1-4, seems to be influential in gliomagenesis. The aim of this study was to investigate EGFR gene amplification and expression of c-erbB1-4 receptor proteins in human anaplastic astrocytomas. Formalin-fixed and paraffin-embedded sections from 31 cases were investigated by standard immunohistochemical procedures for expression of c-erbB1-4 receptor proteins using commercial antibodies. EGFR gene amplification was studied by fluorescence in situ hybridization using paraffin-embedded tissues. Two monoclonal antibodies, NCL-EGFR-384 and NCL-EGFR, were used for EGFR detection and they displayed positive immunoreactivity in $97 \%$ and $71 \%$, respectively. For c-erbB2 detection three monoclonal antibodies, CB11, 3B5, and 5A2, were applied and they displayed positive immunoreactivity in 45\%, 100\%, and 52\%, respectively. Positive immunostaining for c-erbB3 and c-erbB4 was encountered in 97\% and 74\%, respectively. The EGFR gene was amplified in 9 out of 31 tumors (29\%). After adjusting for age, Karnofsky performance status, and extent of surgical resection, Cox multiple regression analysis with overall survival as the dependent variable revealed that c-erbB2 overexpression detected by the monoclonal antibody clone CB11 was a statistically significant poor prognostic factor $(P=0.004)$. This study shows the convenience and feasibility of immunohistochemistry when determining the expression of receptor proteins in tissue sections of human astrocytomas. The synchronous overexpression of c-erbB1-4 proteins in anaplastic astrocytomas supports their role in the pathogenesis of these tumors. Further, c-erbB2 overexpression seems to predict aggressive behaviour.
\end{abstract}

\section{Background}

Anaplastic astrocytomas constitute $4 \%$ of all malignant nervous system tumors [1]. Patients with anaplastic astrocytomas face a poor prognosis despite major efforts to improve radiation, chemotherapy, and surgical procedures. Median survival for patients with anaplastic astrocytoma is 3 to 5 years [2]. Age at diagnosis, extent of surgery and Karnofsky performance score (KPS) are established prognostic factors in high grade glioma patients [3].

The astrocytic tumors are prone to progress, and members of the epidermal growth factor receptor (EGFR) family have been linked to this malignant transformation. This receptor family consists of four tyrosine kinase receptors, c-erbB1-4, and seems to be influential and involved in tumor cell proliferation, differentiation, cell survival, and angiogenesis [4-9]. Coexpression of c-erbB1-4 renders the possibility of dimerization of

\footnotetext{
* Correspondence: sashagulati@hotmail.com
'Department of Neurosurgery, St Olavs University Hospital, Trondheim,

* Correspondence: sashagulati@hotmail.com
'Department of Neurosurgery, St Olavs University Hospital, Trondheim, Norway
}

(c) 2010 Gulati et al; licensee BioMed Central Ltd. This is an Open Access article distributed under the terms of the Creative Commons Attribution License (http://creativecommons.org/licenses/by/2.0), which permits unrestricted use, distribution, and reproduction in any medium, provided the original work is properly cited.

these receptors, thereby recruiting and enhancing signal transducing pathways $[4,7,10]$. Due to overexpression of the c-erbB1-4 receptor proteins and their location on the surface of neoplastic astrocytes, they are attractive candidates for targeted therapy [11-13]. Current strategies include inhibition of the intrinsic kinase activity by monoclonal antibodies [14-16]. Such treatment, however, requires reliable detection systems for these receptor proteins in tumor tissue. Immunohistochemistry appears as the principal mean to detect these receptor proteins. Although this is a convenient and feasible technique, different staining results can be achieved due to varying sensitivity and specificity of commercial antibodies.

Several studies have to a varying degree shown amplification of the EGFR (c-erbB1) gene, located on chromosome 7, in glioblastoma multiforme [17-24]. EGFR gene amplification distinguishes small cell glioblastomas from anaplastic oligodendrogliomas, and it has been shown to be an indicator for resistance to radiotherapy $[25,26]$. EGFR gene amplification can now simply be evaluated 
by means of fluorescence in situ hybdridization (FISH). However, there is limited knowledge concerning the occurrence of EGFR gene amplification and the expression of erb-receptors in anaplastic astrocytomas [27,28].

This study was an extension of our research on erb receptor expression in glioblastomas $[8,29]$, and was designed to investigate the extent of EGFR gene amplification and overexpression in anaplastic astrocytomas. Further, we wanted to explore the expression of other members of the EGFR family in anaplastic astrocytomas and investigate their prognostic significance.

\section{Patients and methods}

All 31 supratentorial human anaplastic astrocytomas were operated at the Department of Neurosurgery, St. Olav University Hospital, Trondheim, Norway, and consecutively collected in the time period 1998 to 2006 . Craniotomies were performed under general anesthesia, with the patient's head resting in a Mayfield frame system (OMI, Inc., Cincinnati, OH, USA) attached to a reference frame for neuronavigation. The preoperative data was imported into an ultrasound-based navigation system and used for surgical planning and resection guidance [30]. All patients underwent magnetic resonance imaging (MRI) a few days before and within 72 hours after surgery. The extent of tumor resection was determined by the postoperative MRI scans. Surgical resection was defined as gross total resection, partial resection, or biopsy. A chart review was performed to collect demographic and clinical data that included age, sex, and symptoms at presentation, tumor localization, treatment modalities, and postoperative survival. Preoperative Karnofsky performance status score was retrospectively determined from a routine neurological examination from patient admittance, one to three days before surgery.
Expression of c-erbB1-4 receptor proteins was determined by immunohistochemistry using various commercial monoclonal antibodies listed in Table 1. Formalin-fixed and paraffin-embedded sections, $4 \mu \mathrm{m}$ thick, with representative tumor tissue, were incubated with primary antibodies after antigen retrieval by pressure cooking. An automatized histostainer was used for the immunohistochemcial procedures (Dako Autostainer, Glostrup, Denmark). For visualization of immunoreactivity, DAKO EnVision system was used with diaminobenzidin as chromogene. Sections were counterstained with haematoxylin. Positive controls were included in each staining run.

The immunoreactivity was assessed by means of intensity and percentage of immunoreactive tumor cells. Intensity was recorded as 0 (no reaction) to 3 (strong reaction). Fraction of immunoreactive tumor cells was recorded as 0 (no positive cells), 1 ( $<10 \%$ positive cells), 2 (10-50\% positive cells), or 3 ( $>50 \%$ positive cells). A staining index was calculated as the product of intensity and fraction of positive tumor cells [8].

EGFR gene copy number was investigated on $4 \mu \mathrm{m}$ thick paraffin sections by double FISH using the LSI EGFR Dual Color Probe- Hyb Set, Vysis no 32-191053 (Abbott Molecular Inc, IL, US). The first probe hybridized with the EGFR gene (chromosomal 7p12 region). Against the centromeric region a second probe was used which revealed the number of copies of chromosome 7 . The sections were deparaffinised using xylene, rehydrated, and pretreated using DAKO solution kit (Histology FISH Accessory kit). The probes were added to the sections, coverslipped, sealed with rubber cement, and placed in a DAKO Hybridizer. The sections and probes were codenatured for $5 \mathrm{~min}$ at $73^{\circ} \mathrm{C}$, followed by annealing at $37^{\circ} \mathrm{C}$ over night. After hybridization slides were washed in $0.4 \times \mathrm{SSC}$ (with detergent) at $73^{\circ} \mathrm{C}$ for two minutes followed by one minutes in $2 \times$ SSC at

Table 1 erbB antibodies used

\begin{tabular}{|c|c|c|c|c|c|c|c|}
\hline Antibody & Source & Type & Clone & Reactant & Positive control & Dilution & $\begin{array}{l}\text { Incubation time and } \\
\text { temperature }\end{array}$ \\
\hline $\begin{array}{l}\text { NCL- } \\
\text { EGFR-384 }\end{array}$ & $\begin{array}{l}\text { Novocastra, Newcastle- } \\
\text { upon-Tyne, UK }\end{array}$ & Monoclonal & EGFR.25 & $\begin{array}{l}\text { EGFR (c-erbB1 protein) } \\
\text { (internal domain) }\end{array}$ & Human skin & $1: 100$ & $\begin{array}{l}60 \text { min. at room } \\
\text { temperature }\end{array}$ \\
\hline$N C L-E G F R$ & Novocastra & Monoclonal & EGFR.113 & $\begin{array}{l}\text { EGFR (c-erbB1 protein) } \\
\text { (external domain) }\end{array}$ & Human skin & $1: 10$ & $\begin{array}{l}60 \text { min. at room } \\
\text { temperature }\end{array}$ \\
\hline c-erbB-2 & Novocastra & Monoclonal & CB11 & $\begin{array}{l}\text { c-erbB2 protein (internal } \\
\text { domain) }\end{array}$ & $\begin{array}{l}\text { SKBR-3 breast } \\
\text { cancer cell line }\end{array}$ & $1: 40$ & $\begin{array}{l}60 \text { min. at room } \\
\text { temperature }\end{array}$ \\
\hline c-erbB-2 & $\begin{array}{l}\text { Immunotech, Marseille, } \\
\text { France }\end{array}$ & Monoclonal & $3 B 5$ & $\begin{array}{l}\text { c-erbB2 protein (internal } \\
\text { domain) }\end{array}$ & $\begin{array}{l}\text { SKBR-3 breast } \\
\text { cancer cell line }\end{array}$ & $\begin{array}{l}\text { Ready to } \\
\text { use }\end{array}$ & $\begin{array}{l}60 \text { min. at room } \\
\text { temperature }\end{array}$ \\
\hline c-erbB-2 & Novocastra & Monoclonal & $5 \mathrm{~A} 2$ & $\begin{array}{l}\text { c-erbB2 protein (internal } \\
\text { domain) }\end{array}$ & $\begin{array}{l}\text { SKBR-3 breast } \\
\text { cancer cell line }\end{array}$ & $1: 50$ & $\begin{array}{l}60 \text { min. at room } \\
\text { temperature }\end{array}$ \\
\hline $\begin{array}{l}\text { NCL-C- } \\
\text { erbB-3 }\end{array}$ & Novocastra & Monoclonal & RTJ1 & c-erbB-3 protein & Normal kidney & $1: 10$ & Over night at $4^{\circ} \mathrm{C}$ \\
\hline $\begin{array}{l}\text { c-erbB-4/ } \\
\text { HER4 }\end{array}$ & $\begin{array}{l}\text { NeoMarkers (Fremont, } \\
\text { CA, USA) }\end{array}$ & Monoclonal & HFR-1 & c-erbB-4 protein & Breast carcinoma & $1: 10$ & Over night at $4^{\circ} \mathrm{C}$ \\
\hline
\end{tabular}


room temperature. Then the sections underwent dehydrating in ethanol three times for $3 \mathrm{~min}$. The slides were counterstained and embedded with a 4,6-diamidino-2-phenylindole/antifade solution (DAKO). FISH signals for each locus-specific FISH probe were assessed under a Nikon Eclipse 90i microscope (Nikon, Tokyo, Japan) using Cytovision software (Applied Imaging, Newcastle upon Tyne, England) equipped with a triplepass filter (DAPI/Green/Orange). The entire area of tumour tissue was evaluated in each case, and all nonoverlapping nuclei were assessed for orange (marker) and green (reference) signals by a pathologist (SHT) blinded to any information about the patients. Using the criteria given by Vysis Inc., for HER-2/neu FISH, EGFR signals to chromosome 7 centromere signals of 2 or greater were considered gene amplification [31].

Statistical analyses were made using SPSS version 16.0 (SPSS Inc., Chicago, IL). Survival time was calculated from date of surgery to date of death. Multiple Cox regression analyses were used to study the association between EGFR receptor protein expression (Staining Index, continuous variable) and survival, adjusting for age at diagnosis (continuous variable), Karnofsky performance status scores (continuous variable), and extent of surgical resection (categorical variable; gross total resection versus partial resection and biopsy). The association between results from the FISH investigations (categorical variables; positive versus negative) and survival were studied in the same manner. Two-sided P-values less than 0.05 were regarded as statistically significant.

The study was approved by the Regional Committee for Medical Research Ethics, and study protocols adhered to guidelines by the Helsinki Convention.

\section{Results}

Thirty-one consecutive patients (13 women and 18 men; mean age, $50.2 \mathrm{yr}$; age range, 28-78 yr) with anaplastic astrocytomas were included in the study. Clinical features of the study group are presented in Table 2. Gross total tumor resection or partial resection was achieved in $10(32 \%)$ and $16(52 \%)$ patients, respectively. In $5(16 \%)$ patients only biopsies were obtained. Four patients had previously undergone surgical resection of diffuse WHO grade II astrocytomas. Chemotherapy and radiotherapy were provided in 7 and 24 cases, respectively.

Immunohistochemical and FISH data are presented in Table 3. In general, the immunoreactivity was localized to either the cell membrane or the cytoplasm or both. The distribution of tumor cells overexpressing erb proteins was both diffuse and dispersed with intensity varying from weak to strong.

Two monoclonal antibodies were used for EGFR detection. NCL-EGFR (clone EGFR.113) is reactive against the external EGFR domain and rendered 22 positive tumors (71\%). NCL-EGFR-384 is directed towards the internal domain, and 30 tumors (97\%) were positive with this antibody.

To determine c-erbB2 expression, three different monoclonal antibodies were applied. The antibody clones $\mathrm{CB} 11,3 \mathrm{~B} 5$, and 5A2 were all reactive against the internal domain and displayed positive immunoreactivity in $45 \%, 100 \%$, and $52 \%$, respectively (Figure $1 \mathrm{~A}$ ).

C-erbB3 immunoreactivity occurred in 27 out of 31 anaplastic astrocytomas (97\%), and c-erbB4 immunoreactivity was present in 23 out of 31 cases (74\%).

The EGFR gene was amplified in 9 out of 31 tumors (29\%) assessed by FISH (Figure 1B).

Multiple Cox regression analysis with overall survival as the dependent variable was performed for clinical disease features with expression of c-erbB1-4 and EGFR gene amplification (Table 4). After adjusting for age, Karnofsky performance status, and extent of surgical resection, the Cox analysis revealed that c-erbB2 overexpression detected by the monoclonal antibody clone CB11 was a statistically significant poor prognostic factor in patients with anaplastic astrocytoma $(P=0.004)$. Neither overexpression of EGFR, c-erbB3, and c-erbB4, nor EGFR gene amplification reached significance.

\section{Discussion}

In this study we have found abundant co-expression of c-erbB1-4 receptor proteins in anaplastic astrocytomas. Cox multiple regression analysis showed that c-erbB2 expression detected by the monoclonal antibody clone CB11 was a statistically significant poor prognostic factor. Additionally, the EGFR gene was amplified in $29 \%$ of the tumors.

The overexpression of EGFR in anaplastic astrocytomas is in line with our earlier report and other studies [24,28,32-34]. Interestingly, the antibody reactive against the cytoplasmic domain unveiled far more immunoreactive tumors than the antibody against the external domain (97\% versus $71 \%$ ). A similar observation was made in our recent report on glioblastomas [8]. A possible explanation might be that the extracellular part of the EGFR is more vulnerable to fixation and tissue processing. It may also be due to proteolytic cleavage and shedding of EGFR as is described for c-erbB2 [35,36]. In any case, further studies must be undertaken to decide which antibody is best suited for standardized EGFR immunohistochemical detection. Such investigations require alternative assays for protein expression, such as protein blotting.

Amplification of the EGFR gene occurs in up to 50\% of human glioblastomas, whereas the reported frequency in anaplastic astrocytomas varies considerably between 
Table 2 Patient characteristics

\begin{tabular}{|c|c|c|c|c|c|c|}
\hline Case no. & Age (years)/Sex & Prior brain tumor & KPS & Resection grade & Radiotherapy & Postoperative survival (months) \\
\hline 1 & $57 / M$ & No & 80 & Partial & $1.8 \mathrm{~Gy} \times 30$ & 16.6 \\
\hline 2 & $34 / F$ & No & 80 & Partial & $1.8 \mathrm{~Gy} \times 30$ & 29.4 \\
\hline 3 & $44 / \mathrm{M}$ & Grade II astrocytoma & 90 & Partial & No & 41.5 \\
\hline 4 & $28 / F$ & No & 90 & GTR & $1.8 \mathrm{~Gy} \times 30$ & 55.4 \\
\hline 5 & $57 / F$ & No & 70 & Partial & $1.8 \mathrm{~Gy} \times 30$ & 5.6 \\
\hline 6 & $50 / M$ & Grade II astrocytoma & 80 & Partial & $1.8 \mathrm{~Gy} \times 30$ & 23.7 \\
\hline 7 & $67 / F$ & No & 80 & Partial & $1.8 \mathrm{~Gy} \times 30$ & 12.1 \\
\hline 8 & $39 / F$ & No & 70 & GTR & N.D. & N.D. \\
\hline 9 & $53 / \mathrm{M}$ & No & 70 & Partial & $1.8 \mathrm{~Gy} \times 30$ & 24.6 \\
\hline 10 & $78 / F$ & No & 50 & Biopsy & $3.0 \mathrm{~Gy} \times 13$ & 9.8 \\
\hline 11 & $34 / F$ & No & 80 & Partial & $1.8 \mathrm{~Gy} \times 30$ & $95.8+$ \\
\hline 12 & $42 / \mathrm{M}$ & No & 70 & GTR & $1.8 \mathrm{~Gy} \times 30$ & $93.6+$ \\
\hline 13 & $78 / \mathrm{M}$ & No & 50 & Biopsy & No & 1.9 \\
\hline 14 & $40 / \mathrm{M}$ & No & 70 & GTR & $1.8 \mathrm{~Gy} \times 30$ & 53.9 \\
\hline 15 & $47 / M$ & Grade II astrocytoma & 90 & GTR & No & $90+$ \\
\hline 16 & $49 / M$ & No & 50 & Biopsy & No & 0.1 \\
\hline 17 & $64 / M$ & No & 70 & GTR & $1.8 \mathrm{~Gy} \times 30$ & $76.1+$ \\
\hline 18 & $48 / F$ & No & 80 & GTR & $1.8 \mathrm{~Gy} \times 30$ & 8.3 \\
\hline 19 & $57 / F$ & No & 80 & Partial & $1.8 \mathrm{~Gy} \times 30$ & $63.8+$ \\
\hline 20 & $72 / \mathrm{M}$ & No & 60 & Biopsy & $1.8 \mathrm{~Gy} \times 30$ & 11.1 \\
\hline 21 & $36 / \mathrm{M}$ & No & 70 & Partial & $3.0 \mathrm{~Gy} \times 13$ & 11.2 \\
\hline 22 & $56 / F$ & No & 70 & Partial & $2.0 \mathrm{~Gy} \times 30$ & 17.9 \\
\hline 23 & $53 / F$ & No & 80 & GTR & $2.0 \mathrm{~Gy} \times 30$ & $59.8+$ \\
\hline 24 & $44 / F$ & No & 80 & GTR & No & $59.8+$ \\
\hline 25 & $37 / M$ & No & 80 & GTR & No & $54.6+$ \\
\hline 26 & $58 / \mathrm{M}$ & No & 80 & Partial & $1.8 \mathrm{~Gy} \times 30$ & 28.6 \\
\hline 27 & $32 / F$ & No & 70 & Partial & $2.0 \mathrm{~Gy} \times 30$ & 16.2 \\
\hline 28 & $38 / \mathrm{M}$ & No & 80 & Partial & $2.0 \mathrm{~Gy} \times 30$ & $35.3+$ \\
\hline 29 & $71 / \mathrm{M}$ & No & 50 & Biopsy & $3.0 \mathrm{~Gy} \times 13$ & 10.2 \\
\hline 30 & $49 / M$ & No & 70 & Partial & $2.0 \mathrm{~Gy} \times 30$ & $30.6+$ \\
\hline 31 & $44 / M$ & Grade II astrocytoma & 80 & Partial & $1.8 \mathrm{~Gy} \times 30$ & $39.4+$ \\
\hline
\end{tabular}

$\mathrm{M}=$ Male, $\mathrm{F}=$ Female, KPS = Karnofsky Performance Status, GTR $=$ Gross total resection, N.D. $=$ No data. $(+)$ denotes that the patient is still alive.

none to about one third of the cases [23,24,28,32,37-40]. Different techniques and definitions of gene dosage may explain these conflicting data. In this regard, FISH analyses have turned out to be a simple and reliable method $[28,32]$. In our series of anaplastic astrocytomas this approach revealed a relatively high frequency of EGFR gene amplification with $29 \%$ of the tumors exhibiting this genetic rearrangement. It seems this genetic event is not solely confined to glioblastomas, and it may be coupled to the malignant progression of anaplastic astrocytomas. It remains to be shown whether this gene amplification is a cause or a consequence of tumor progression. Nevertheless, it may be involved in the oncogenesis of both primary and secondary glioblastomas. Overexpression of EGFR in astrocytomas can also occur without gene amplification $[8,28,32,37,39]$, suggesting other mechanisms at transcriptional and translational levels. An amplified EGFR gene may lead to expression of mutant EGFR (EGFRvIII) in high grade astrocytomas [27], providing a possible target for immunotherapy [41]. Even though there are several studies advocating the importance of EGFR in the oncogenesis of astrocytomas [5,9], the prognostic role of EGFR overexpression and EGFR gene amplification is still not fully clarified $[5,8,9,27,31,39,42-46]$. Neither EGFR gene amplification nor EGFR overexpression was associated with survival in this study. Conflicting prognostic data may be related to various techniques and small series of tumors studied, so larger studies are required to explore the prognostic impact of EGFR.

$\mathrm{C}-\mathrm{erbB} 2$ is already an established negative prognostic marker with an associated targeted therapy in human breast cancer [47]. It has been suggested that c-erbB2 is a preferred partner for heterodimerization with the other members of the EGFR family. The physiological ligand of c-erbB2 has not been identified, and it is 
Table 3 Immunohistochemical and FISH data

\begin{tabular}{|c|c|c|c|c|c|c|c|c|}
\hline Case no. & $\begin{array}{l}\text { c-erbB-1 } \\
\text { (clone EGFR.25) } \\
\text { (internal } \\
\text { domain) } \\
\end{array}$ & $\begin{array}{l}\text { c-erbB-1 } \\
\text { (clone EGFR.113) } \\
\text { (external domain) }\end{array}$ & $\begin{array}{l}\text { c-erbB-2 } \\
\text { (clone CB11) } \\
\text { (internal } \\
\text { domain) } \\
\end{array}$ & $\begin{array}{l}\text { c-erbB-2 } \\
\text { (clone 3B5) } \\
\text { (internal } \\
\text { domain) } \\
\end{array}$ & $\begin{array}{l}\text { c-erbB-2 } \\
\text { (clone 5A2) } \\
\text { (internal } \\
\text { domain) } \\
\end{array}$ & c-erbB-3 & c-erbB-4 & $\begin{array}{l}\text { EGFR gene } \\
\text { amplification } \\
\text { (FISH) }\end{array}$ \\
\hline 1 & 9 & 9 & 4 & 6 & 6 & 9 & 4 & Yes \\
\hline 2 & 9 & 1 & 0 & 9 & 3 & 4 & 2 & No \\
\hline 3 & 6 & 0 & 4 & 3 & 1 & 9 & 0 & No \\
\hline 4 & 6 & 1 & 1 & 9 & 0 & 0 & 0 & No \\
\hline 5 & 0 & 0 & 4 & 6 & 2 & 6 & 4 & No \\
\hline 6 & 1 & 9 & 1 & 4 & 0 & 4 & 0 & Yes \\
\hline 7 & 9 & 9 & 0 & 1 & 0 & 0 & 0 & No \\
\hline 8 & 6 & 2 & 0 & 6 & 4 & 6 & 4 & Yes \\
\hline 9 & 9 & 9 & 2 & 6 & 0 & 6 & 6 & No \\
\hline 10 & 9 & 9 & 0 & 9 & 1 & 9 & 4 & Yes \\
\hline 11 & 4 & 0 & 2 & 6 & 0 & 4 & 4 & Yes \\
\hline 12 & 9 & 4 & 0 & 6 & 2 & 9 & 2 & Yes \\
\hline 13 & 9 & 2 & 4 & 6 & 1 & 9 & 2 & No \\
\hline 14 & 4 & 0 & 0 & 1 & 0 & 0 & 0 & No \\
\hline 15 & 2 & 1 & 0 & 9 & 1 & 6 & 0 & No \\
\hline 16 & 6 & 0 & 0 & 4 & 0 & 6 & 1 & No \\
\hline 17 & 9 & 2 & 0 & 9 & 4 & 9 & 2 & No \\
\hline 18 & 4 & 1 & 6 & 9 & 1 & 4 & 4 & No \\
\hline 19 & 4 & 0 & 0 & 1 & 0 & 4 & 0 & Yes \\
\hline 20 & 6 & 1 & 1 & 6 & 0 & 6 & 1 & Yes \\
\hline 21 & 6 & 4 & 1 & 6 & 0 & 4 & 2 & No \\
\hline 22 & 9 & 6 & 2 & 6 & 6 & 4 & 2 & No \\
\hline 23 & 9 & 3 & 0 & 6 & 0 & 1 & 0 & No \\
\hline 24 & 6 & 0 & 0 & 6 & 3 & 6 & 2 & No \\
\hline 25 & 6 & 2 & 1 & 6 & 3 & 9 & 2 & No \\
\hline 26 & 6 & 4 & 6 & 6 & 2 & 4 & 1 & Yes \\
\hline 27 & 6 & 0 & 0 & 1 & 0 & 2 & 1 & No \\
\hline 28 & 6 & 1 & 0 & 4 & 0 & 4 & 1 & No \\
\hline 29 & 9 & 6 & 0 & 4 & 0 & 0 & 1 & No \\
\hline 30 & 3 & 0 & 0 & 4 & 0 & 2 & 2 & No \\
\hline 31 & 6 & 1 & 0 & 9 & 3 & 9 & 6 & No \\
\hline $\begin{array}{l}\text { Median } \\
\text { Staining } \\
\text { Index }\end{array}$ & 6 & 1 & 0 & 6 & 1 & 4 & 2 & \\
\hline $\begin{array}{l}\text { No. of } \\
\text { positive } \\
\text { cases/Total } \\
\text { no. of cases }\end{array}$ & $30 / 31$ & $22 / 31$ & $14 / 31$ & $31 / 31$ & $16 / 31$ & $27 / 31$ & $23 / 31$ & $9 / 31$ \\
\hline $\begin{array}{l}\text { Percentage } \\
\text { positivity }\end{array}$ & $97 \%$ & $71 \%$ & $45 \%$ & $100 \%$ & $52 \%$ & $97 \%$ & $74 \%$ & $29 \%$ \\
\hline
\end{tabular}

possible that this receptor can undergo homo- and heterodimerization in the absence of ligand binding [48]. In our series of anaplastic astrocytomas, three different antibodies were applied for detection of the c-erbB2 receptor protein in tumor tissue. They were all reactive against the internal domain and provided satisfactory immunostainings. In line with divergent reports on the presence of this receptor in malignant astrocytomas $[8,21,49-55]$, the number of immunoreactive tumors differed considerably between the antibodies used. This can partly be explained by the application of different antibodies, subjective assessments of immunostaining, differences in tissue processing, and small sample series. Accordingly, the reported prognostic power of this receptor protein is debatable as well. Even so, reports including the present study point to an unfavourable outcome in neuroepithelial tumors with c-erbB-2 overexpression [51,52,56,57]. 


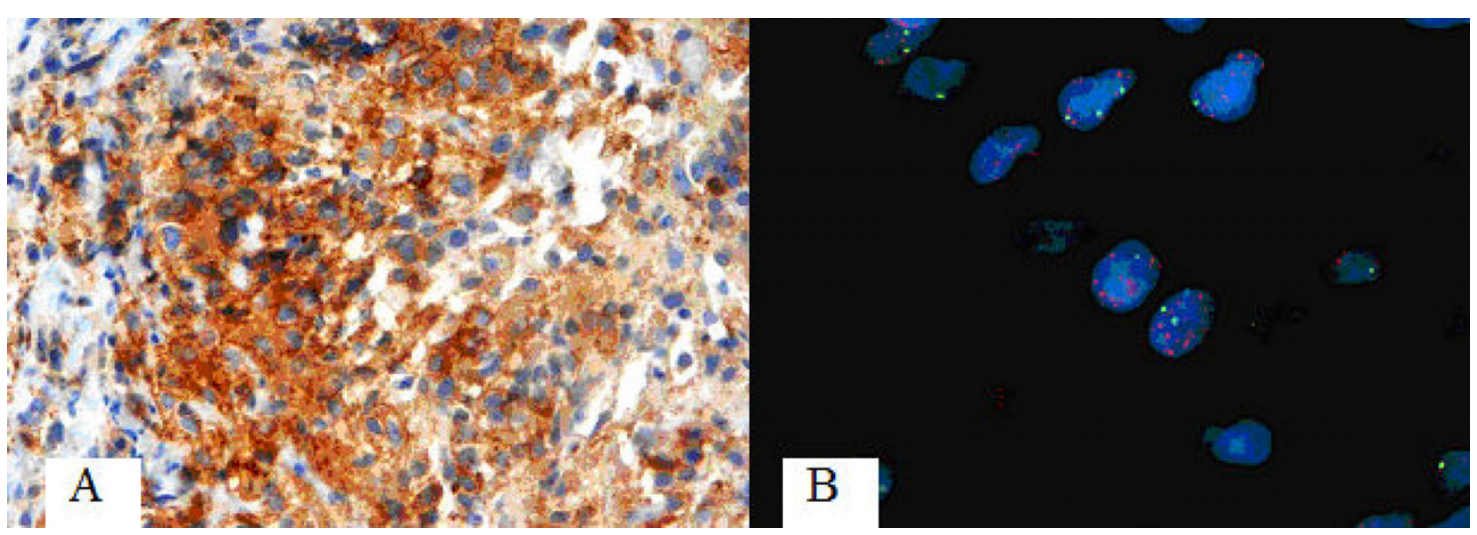

Figure 1 (A) Positive immunoreactivity for c-erbB2 (clone CB-11) (40X). (B) FISH analysis showing EGFR gene amplification (Chromosome 7 centromeric probe in green, EGFR probe in red).

Table 4 Results from multiple Cox regression analyses

\begin{tabular}{|c|c|c|c|}
\hline Variable & Hazard ratio & 95\% Confidence interval & $P$ \\
\hline c-erbB1 (clone EGFR.113) staining index & 1.076 & 0.92 to 1.26 & 0.37 \\
\hline Karnofsky performance status & 0.913 & 0.85 to 0.98 & 0.008 \\
\hline Gross total resection & 0.196 & 0.05 to 0.79 & 0.022 \\
\hline Age & 0.998 & 0.95 to 1.05 & 0.95 \\
\hline c-erbB1 (clone EGFR.25) staining index & 0.991 & 0.80 to 1.23 & 0.93 \\
\hline Karnofsky performance status & 0.912 & 0.85 to 0.98 & 0.009 \\
\hline Gross total resection & 0.199 & 0.05 to 0.82 & 0.026 \\
\hline Age & 1.007 & 0.96 to 1.06 & 0.79 \\
\hline c-erbB2 (clone CB11) staining index & 1.642 & 1.17 to 2.30 & 0.004 \\
\hline Karnofsky performance status & 0.854 & 0.78 to 0.94 & 0.001 \\
\hline Gross total resection & 0.324 & 0.08 to 1.38 & 0.13 \\
\hline Age & 0.973 & 0.92 to 1.03 & 0.36 \\
\hline c-erbB2 (clone 5A2) staining index & 1.036 & 0.79 to 1.35 & 0.80 \\
\hline Karnofsky performance status & 0.910 & 0.85 to 0.98 & 0.009 \\
\hline Gross total resection & 0.186 & 0.05 to 0.78 & 0.021 \\
\hline Age & 1.005 & 0.96 to 1.06 & 0.85 \\
\hline c-erbB2 (clone 3B5) staining index & 1.018 & 0.84 to 1.23 & 0.86 \\
\hline Karnofsky performance status & 0.912 & 0.85 to 0.98 & 0.009 \\
\hline Gross total resection & 0.190 & 0.05 to 0.77 & 0.020 \\
\hline Age & 1.006 & 0.96 to 1.06 & 0.81 \\
\hline c-erbB3 (clone RTJ1) staining index & 0.975 & 0.83 to 1.15 & 0.76 \\
\hline Karnofsky performance status & 0.914 & 0.85 to 0.98 & 0.010 \\
\hline Gross total resection & 0.204 & 0.05 to 0.81 & 0.024 \\
\hline Age & 1.008 & 0.96 to 1.06 & 0.74 \\
\hline c-erbB4 (clone HFR-1) staining index & 0.902 & 0.68 to 1.20 & 0.48 \\
\hline Karnofsky performance status & 0.907 & 0.85 to 0.97 & 0.005 \\
\hline Gross total resection & 0.178 & 0.05 to 0.72 & 0.015 \\
\hline Age & 1.003 & 0.96 to 1.05 & 0.90 \\
\hline EGFR gene amplification & 0.689 & 0.23 to 2.11 & 0.51 \\
\hline Karnofsky performance status & 0.919 & 0.86 to 0.99 & 0.021 \\
\hline Gross total resection & 0.175 & 0.04 to 0.73 & 0.017 \\
\hline Age & 1.013 & 0.96 to 1.07 & 0.63 \\
\hline
\end{tabular}

Multiple Cox regression analyses were used to study the association between c-erbB1-4 expression and survival, adjusting for age at diagnosis, Karnofsky performance status scores, and extent of surgical resection. The association between EGFR amplification and survival was studied in the same manner. 
Unlike breast cancer, gene amplification is not a prerequisite for overexpression in gliomas $[49,58]$ and FISH analyses are therefore superfluous in this context.

The overexpression of c-erbB3 and c-erbB 4 is in accordance with our previous study on glioblastomas as well as with others $[8,21,54,59,60]$. These findings suggest involvement of these two receptor proteins in the oncogenesis of astrocytomas. However, no association with survival was detected in our study. By forming heterodimers with other members of the EGFR family, cerbB3 channels erbB signaling through the PI3K/Akt pathway which in turn promotes tumor growth and progression. This phenomenon may limit the impact of exclusively targeting EGFR and c-erbB2 proteins, and may explain the acquired resistance to anticancer drugs that inhibit receptor tyrosine kinases [61]. The close integration of different $e r b \mathrm{~B}$ signaling systems and their interactions with other tyrosine kinases such as IGF1-R and c-met, suggest that the members of the EGFR family should be dealt with as a group rather than individually.

The role of c-erbB4 in tumorigenesis has not been fully established. Cooperation between erb proteins may also be of clinical relevance as mutual expression of c$e r b \mathrm{~B} 2$ and c-erbB4 serves as an independent negative prognostic factor in childhood medulloblastoma [56]. A unique feature for c-erbB4 is that pre-mRNA undergoes alternative splicing, generating structurally distinct isoforms. The c-erbB4 isoforms have different signalling capabilities and may lead to diverse cellular responses. This might explain the inconsistent reports evaluating the role of c-erbB4 in breast cancer [62].

This retrospective study has limitations typical of immunohistochemical approaches, including limited technical reproducibility and subjective interpretation. In summary, this study shows the convenience and feasibility of immunohistochemistry when determining the expression of receptor proteins in tumor tissue. Our findings indicate that c-erbB2 overexpression predicts aggressive behaviour in human anaplastic astrocytomas. The coexpression of members of the EGFR family underlines their role in the oncogenesis of anaplastic astrocytomas and supports their promising clinical relevance in regard to prognosis, diagnosis, and therapy.

\footnotetext{
Abbreviations

EGFR: Epidermal growth factor receptor; FISH: Fluorescence in situ hybridization; KPS: Karnofsky performance status; GTR: Gross total resection; MRI: Magnetic resonance imaging; WHO: World Health Organization; N.D: No data.
}

\section{Author details}

'Department of Neurosurgery, St Olavs University Hospital, Trondheim, Norway. ${ }^{2}$ Department of Laboratory Medicine, Children's and Women's Health, Norwegian University of Science and Technology, Trondheim, Norway. ${ }^{3}$ Department of Pathology and Medical Genetics, St Olavs University
Hospital, Trondheim, Norway. ${ }^{4}$ Department of Circulation and Medical Imaging, Norwegian University of Science and Technology, Trondheim, Norway. ${ }^{5}$ Department of Cancer Research and Molecular Medicine, Norwegian University of Science and Technology, Trondheim, Norway.

\section{Authors' contributions}

SG carried out the experiments, collected and interpretated the data, and wrote the manuscript. BY carried out the experiments and wrote the manuscript. USG carried out the experiments and wrote the manuscript. MG collected data and wrote the manuscript. SL analyzed the data and wrote the manuscript. SHT contributed conception, designed the study, and wrote the manuscript. All authors read and approved the final manuscript.

\section{Competing interests}

SG has received grants from Sparebanken Møre and The Family Blix Fund for medical research. The other authors have no competing interests.

Received: 4 February 2010 Accepted: 23 March 2010

Published: 23 March 2010

\section{References}

1. Stupp R, Reni M, Gatta G, Mazza E, Vecht C: Anaplastic astrocytoma in adults. Crit Rev Oncol Hematol 2007, 63:72-80.

2. Chang SM, Parney IF, Huang W, Anderson FA Jr, Asher AL, Bernstein M, Lillehei KO, Brem H, Berger MS, Laws ER, Glioma Outcomes Project I: Patterns of care for adults with newly diagnosed malignant glioma. JAMA 2005, 293:557-564.

3. Buckner JC: Factors influencing survival in high-grade gliomas. Semin Oncol 2003, 30:10-14

4. Bazley LA, Gullick WJ: The epidermal growth factor receptor family. Endocr Relat Cancer 2005, 12(Suppl 1):S17-27.

5. Hamel W, Westphal M: Growth factors in gliomas revisited. Acta Neurochir (Wien) 2000, 142:113-137, discussion 137-118.

6. Kuan CT, Wikstrand CJ, Bigner DD: EGF mutant receptor vill as a molecular target in cancer therapy. Endocr Relat Cancer 2001, 8:83-96.

7. Schlessinger J: Cell signaling by receptor tyrosine kinases. Cell 2000, 103:211-225.

8. Torp SH, Gulati S, Johannessen E, Dalen A: Coexpression of c-erbB 1-4 receptor proteins in human glioblastomas. An immunohistochemical study. J Exp Clin Cancer Res 2007, 26:353-359.

9. Weiner $\mathrm{HL}$ : The role of growth factor receptors in central nervous system development and neoplasia. Neurosurgery 1995, 37:179-193, discussion 193-174

10. Schlessinger J: Ligand-induced, receptor-mediated dimerization and activation of EGF receptor. Cell 2002, 110:669-672.

11. Halatsch ME, Schmidt U, Behnke-Mursch J, Unterberg A, Wirtz CR: Epidermal growth factor receptor inhibition for the treatment of glioblastoma multiforme and other malignant brain tumours. Cancer Treat Rev 2006, 32:74-89.

12. Herbst RS, Shin DM: Monoclonal antibodies to target epidermal growth factor receptor-positive tumors: a new paradigm for cancer therapy. Cancer 2002, 94:1593-1611.

13. Mischel PS, Cloughesy TF: Targeted molecular therapy of GBM. Brain Pathol 2003, 13:52-61.

14. Contessa JN, Hamstra DA: Revoking the privilege: targeting HER2 in the central nervous system. Mol Pharmacol 2008, 73:271-273.

15. Voelzke WR, Petty WJ, Lesser GJ: Targeting the epidermal growth factor receptor in high-grade astrocytomas. Curr Treat Options Oncol 2008, 9:23-31.

16. Emanuel SL, Hughes TV, Adams M, Rugg CA, Fuentes-Pesquera A, Connolly PJ, Pandey N, Moreno-Mazza S, Butler J, Borowski V, et al: Cellular and in vivo activity of JNJ-2887 a nonquinazoline pan-ErbB kinase inhibitor that crosses the blood-brain barrier and displays efficacy against intracranial tumors. Mol Pharmacol 1063, 73:338-348.

17. Libermann TA, Nusbaum HR, Razon N, Kris R, Lax I, Soreq H, Whittle N Waterfield MD, Ullrich A, Schlessinger J: Amplification, enhanced expression and possible rearrangement of EGF receptor gene in primary human brain tumours of glial origin. Nature 1985, 313:144-147.

18. Liu L, Ichimura K, Pettersson EH, Collins VP: Chromosome 7 rearrangements in glioblastomas; loci adjacent to EGFR are independently amplified. J Neuropathol Exp Neurol 1998, 57:1138-1145. 
19. Sauter G, Maeda T, Waldman FM, Davis RL, Feuerstein BG: Patterns of epidermal growth factor receptor amplification in malignant gliomas. Am J Pathol 1996, 148:1047-1053.

20. Schlegel J, Merdes A, Stumm G, Albert FK, Forsting M, Hynes N, Kiessling M: Amplification of the epidermal-growth-factor-receptor gene correlates with different growth behaviour in human glioblastoma. Int J Cancer 1994, 56:72-77.

21. Schlegel J, Stumm G, Brandle K, Merdes A, Mechtersheimer G, Hynes NE, Kiessling $\mathrm{M}$ : Amplification and differential expression of members of the erbB-gene family in human glioblastoma. J Neurooncol 1994, 22:201-207.

22. Schober R, Bilzer T, Waha A, Reifenberger G, Wechsler W, von Deimling A, Wiestler OD, Westphal M, Kemshead JT, Vega F, et al: The epidermal growth factor receptor in glioblastoma: genomic amplification, protein expression, and patient survival data in a therapeutic trial. Clin Neuropathol 1995, 14:169-174.

23. von Deimling A, Louis DN, von Ammon K, Petersen I, Hoell T, Chung RY, Martuza RL, Schoenfeld DA, Yasargil MG, Wiestler OD, et al: Association of epidermal growth factor receptor gene amplification with loss of chromosome 10 in human glioblastoma multiforme. J Neurosurg 1992, 77:295-301.

24. Wong AJ, Bigner SH, Bigner DD, Kinzler KW, Hamilton SR, Vogelstein B: Increased expression of the epidermal growth factor receptor gene in malignant gliomas is invariably associated with gene amplification. Proc Natl Acad Sci USA 1987, 84:6899-6903.

25. Barker FG, Simmons ML, Chang SM, Prados MD, Larson DA, Sneed PK, Wara WM, Berger MS, Chen P, Israel MA, Aldape KD: EGFR overexpression and radiation response in glioblastoma multiforme. Int I Radiat Oncol Biol Phys 2001, 51:410-418.

26. Krishnan S, Rao RD, James CD, Sarkaria JN: Combination of epidermal growth factor receptor targeted therapy with radiation therapy for malignant gliomas. Front Biosci 2003, 8:e1-13.

27. Aldape KD, Ballman K, Furth A, Buckner JC, Giannini C, Burger PC, Scheithauer BW, Jenkins RB, James CD: Immunohistochemical detection of EGFRvIll in high malignancy grade astrocytomas and evaluation of prognostic significance. J Neuropathol Exp Neurol 2004, 63:700-707.

28. Guillaudeau A, Durand K, Pommepuy I, Robert S, Chaunavel A, Lacorre S, DeArmas R, Bourtoumieux S, El Demery M, Moreau JJ, Labrousse F: Determination of EGFR status in gliomas: usefulness of immunohistochemistry and fluorescent in situ hybridization. Appl Immunohistochem Mol Morphol 2009, 17:220-226.

29. Torp SH, Bringedal K, Dalen A: Immunohistochemical detection of epidermal growth factor receptor in human high-grade astrocytomas-a comparison between frozen- and paraffin sections. J Exp Clin Cancer Res 2005, 24:89-92

30. Gulati S, Berntsen EM, Solheim O, Kvistad KA, Haberg A, Selbekk T, Torp SH, Unsgaard G: Surgical resection of high-grade gliomas in eloquent regions guided by blood oxygenation level dependent functional magnetic resonance imaging, diffusion tensor tractography, and intraoperative navigated 3D ultrasound. Minim Invasive Neurosurg 2009, 52:17-24.

31. Layfield LJ, Willmore C, Tripp S, Jones C, Jensen RL: Epidermal growth factor receptor gene amplification and protein expression in glioblastoma multiforme: prognostic significance and relationship to other prognostic factors. Appl Immunohistochem Mol Morphol 2006, 14:91-96.

32. Marquez A, Wu R, Zhao J, Tao J, Shi Z: Evaluation of epidermal growth factor receptor (EGFR) by chromogenic in situ hybridization (CISH) and immunohistochemistry (IHC) in archival gliomas using bright-field microscopy. Diagn Mol Pathol 2004, 13:1-8.

33. Reifenberger G, Prior R, Deckert M, Wechsler W: Epidermal growth factor receptor expression and growth fraction in human tumours of the nervous system. Virchows Arch A Pathol Anat Histopathol 1989, 414:147-155.

34. Torp SH, Helseth E, Dalen A, Unsgaard G: Epidermal growth factor receptor expression in human gliomas. Cancer Immunol Immunother 1991, 33:61-64.

35. Perez-Torres M, Valle BL, Maihle NJ, Negron-Vega L, Nieves-Alicea R, Cora EM: Shedding of epidermal growth factor receptor is a regulated process that occurs with overexpression in malignant cells. Exp Cell Res 2008, 314:2907-2918.
36. Zabrecky JR, Lam T, McKenzie SJ, Carney W: The extracellular domain of p185/neu is released from the surface of human breast carcinoma cells, SK-BR-3. J Biol Chem 1991, 266:1716-1720.

37. Ekstrand AJ, James CD, Cavenee WK, Seliger B, Pettersson RF, Collins VP: Genes for epidermal growth factor receptor, transforming growth factor alpha, and epidermal growth factor and their expression in human gliomas in vivo. Cancer Res 1991, 51:2164-2172.

38. Hurtt MR, Moossy J, Donovan-Peluso M, Locker J: Amplification of epidermal growth factor receptor gene in gliomas: histopathology and prognosis. J Neuropathol Exp Neurol 1992, 51:84-90.

39. Jarvela $S$, Helin $H$, Haapasalo J, Jarvela T, Junttila TT, Elenius $K$, Tanner $M$, Haapasalo H, Isola J: Amplification of the epidermal growth factor receptor in astrocytic tumours by chromogenic in situ hybridization: association with clinicopathological features and patient survival. Neuropathol Appl Neurobiol 2006, 32:441-450.

40. Smith JS, Tachibana I, Passe SM, Huntley BK, Borell TJ, Iturria N, O'Fallon JR, Schaefer PL, Scheithauer BW, James CD, et al: PTEN mutation, EGFR amplification, and outcome in patients with anaplastic astrocytoma and glioblastoma multiforme. J Natl Cancer Inst 2001, 93:1246-1256.

41. Choi BD, Archer GE, Mitchell DA, Heimberger AB, McLendon RE, Bigner DD, Sampson JH: EGFRvIll-targeted vaccination therapy of malignant glioma. Brain Pathol 2009, 19:713-723.

42. Bouvier-Labit C, Chinot O, Ochi C, Gambarelli D, Dufour H, FigarellaBranger D: Prognostic significance of Ki67, p53 and epidermal growth factor receptor immunostaining in human glioblastomas. Neuropathol Appl Neurobiol 1998, 24:381-388.

43. Newcomb EW, Cohen H, Lee SR, Bhalla SK, Bloom J, Hayes RL, Miller DC: Survival of patients with glioblastoma multiforme is not influenced by altered expression of p16, p53, EGFR, MDM2 or Bcl-2 genes. Brain Pathol 1998, 8:655-667.

44. Olson JJ, Barnett D, Yang J, Assietti R, Cotsonis G, James CD: Gene amplification as a prognostic factor in primary brain tumors. Clin Cancer Res 1998, 4:215-222.

45. Shinojima N, Tada K, Shiraishi S, Kamiryo T, Kochi M, Nakamura H, Makino K, Saya $\mathrm{H}$, Hirano H, Kuratsu J, et al: Prognostic value of epidermal growth factor receptor in patients with glioblastoma multiforme. Cancer Res 2003, 63:6962-6970.

46. Torp SH, Helseth E, Dalen A, Unsgaard G: Relationships between Ki-67 labelling index, amplification of the epidermal growth factor receptor gene, and prognosis in human glioblastomas. Acta Neurochir (Wien) 1992, 117:182-186

47. Cheang MC, Chia SK, Voduc D, Gao D, Leung S, Snider J, Watson M, Davies S, Bernard PS, Parker JS, et al: Ki67 index, HER2 status, and prognosis of patients with luminal B breast cancer. J Natl Cancer Inst 2009, 101:736-750

48. Graus-Porta D, Beerli RR, Daly JM, Hynes NE: ErbB-2, the preferred heterodimerization partner of all ErbB receptors, is a mediator of lateral signaling. $E M B O J$ I 1997, 16:1647-1655

49. Haapasalo H, Hyytinen E, Sallinen P, Helin H, Kallioniemi OP, Isola J: c-erbB2 in astrocytomas: infrequent overexpression by immunohistochemistry and absence of gene amplification by fluorescence in situ hybridization. Br J Cancer 1996, 73:620-623.

50. Haynik DM, Roma AA, Prayson RA: HER-2/neu expression in glioblastoma multiforme. Appl Immunohistochem Mol Morphol 2007, 15:56-58.

51. Mineo JF, Bordron A, Baroncini M, Maurage CA, Ramirez C, Siminski RM, Berthou C, Dam Hieu P: Low HER2-expressing glioblastomas are more often secondary to anaplastic transformation of low-grade glioma. J Neurooncol 2007, 85:281-287.

52. Potti A, Forseen SE, Koka VK, Pervez H, Koch M, Fraiman G, Mehdi SA, Levitt R: Determination of HER-2/neu overexpression and clinical predictors of survival in a cohort of 347 patients with primary malignant brain tumors. Cancer Invest 2004, 22:537-544.

53. Schwechheimer K, Laufle RM, Schmahl W, Knodlseder M, Fischer $H$, Hofler H: Expression of neu/c-erbB-2 in human brain tumors. Hum Pathol 1994, 25:772-780.

54. Andersson U, Guo D, Malmer B, Bergenheim AT, Brannstrom T, Hedman H, Henriksson R: Epidermal growth factor receptor family (EGFR, ErbB2-4) in gliomas and meningiomas. Acta Neuropathol 2004, 108:135-142.

55. Torp $S H$, Helseth E, Unsgaard G, Dalen A: C-erbB-2/HER-2 protein in human intracranial tumours. Eur J Cancer 1993, 29A:1604-1606. 
56. Gilbertson RJ, Perry RH, Kelly PJ, Pearson AD, Lunec J: Prognostic significance of HER2 and HER4 coexpression in childhood medulloblastoma. Cancer Res 1997, 57:3272-3280.

57. Koka V, Potti A, Forseen SE, Pervez H, Fraiman GN, Koch M, Levitt R: Role of Her-2/neu overexpression and clinical determinants of early mortality in glioblastoma multiforme. Am J Clin Oncol 2003, 26:332-335.

58. Slamon DJ, Godolphin W, Jones LA, Holt JA, Wong SG, Keith DE, Levin WJ, Stuart SG, Udove J, Ullrich A, et al: Studies of the HER-2/neu protooncogene in human breast and ovarian cancer. Science 1989, 244:707-712.

59. Srinivasan R, Poulsom R, Hurst HC, Gullick WJ: Expression of the c-erbB-4/ HER4 protein and mRNA in normal human fetal and adult tissues and in a survey of nine solid tumour types. J Pathol 1998, 185:236-245.

60. Westphal M, Meima L, Szonyi E, Lofgren J, Meissner H, Hamel W, Nikolics K, Sliwkowski MX: Heregulins and the ErbB-2/3/4 receptors in gliomas. J Neurooncol 1997, 35:335-346.

61. Stern DF: ERBB3/HER3 and ERBB2/HER2 duet in mammary development and breast cancer. J Mammary Gland Biol Neoplasia 2008, 13:215-223.

62. Sundvall M, Iljin K, Kilpinen S, Sara H, Kallioniemi OP, Elenius K: Role of ErbB4 in breast cancer. J Mammary Gland Biol Neoplasia 2008, 13:259-268.

doi:10.1186/1746-1596-5-18

Cite this article as: Gulati et al:: Overexpression of c-erbB2 is a negative prognostic factor in anaplastic astrocytomas. Diagnostic Pathology 2010 5:18.

\section{Submit your next manuscript to BioMed Central} and take full advantage of:

- Convenient online submission

- Thorough peer review

- No space constraints or color figure charges

- Immediate publication on acceptance

- Inclusion in PubMed, CAS, Scopus and Google Scholar

- Research which is freely available for redistribution

Submit your manuscript at www.biomedcentral.com/submit 